\title{
Knockdown of FSTL1 inhibits PDGF-BB-induced human airway smooth muscle cell proliferation and migration
}

\author{
YUELIN DENG, YAO ZHANG, HUAJIE WU, ZHAOLING SHI and XIN SUN \\ Department of Pediatrics, Xijing Hospital, The Fourth Military Medical University, Xi'an, Shaanxi 710032, P.R. China
}

Received November 10, 2015; Accepted November 14, 2016

DOI: $10.3892 / \mathrm{mmr} .2017 .6439$

\begin{abstract}
Abnormal proliferation and migration of airway smooth muscle (ASM) cells serve roles in airway remodeling, and contribute to airway hyper-responsiveness. Follistatin-like protein 1 (FSTL1) is a secreted glycoprotein that belongs to the follistatin family of proteins. It was reported that in the lungs of patients suffering from severe asthma, FSTL1 is highly expressed by macrophages. However, the role of FSTL1 in ASM cell proliferation and migration remains unknown. The present study aimed to investigate the role of FSTL1 in cell proliferation and migration mediated by platelet-derived growth factor subunit B (PDGF-BB) in human ASM cells. The results of the present study demonstrated that PDGF-BB stimulation upregulated FSTL1 expression levels in ASM cells in vitro. Knockdown of FSTL1 inhibited cell proliferation and arrested the cell cycle in the G2/M phase in PDGF-BB-stimulated ASM cells. Additionally, knockdown of FSTL1 inhibited PDGF-BB-induced ASM cell migration. Furthermore, FSTL1 knockdown caused the downregulation of phosphorylated (p)-extracellular signal-regulated kinase (ERK) and p-protein kinase B (AKT) expression levels induced by PDGF-BB in ASM cells. In conclusion, the present study demonstrated that knockdown of FSTL1 inhibited ASM cell proliferation and migration induced by PDGF-BB, at least partially via inhibiting the activation of ERK and AKT. FSTL1 may therefore represent a novel therapeutic target for airway remodeling in childhood asthma.
\end{abstract}

\section{Introduction}

Childhood asthma is a group of multifactorial diseases with similar features, including mast cell and eosinophil infiltration, causing airway hyper-responsiveness, inflammation and airway obstruction (1). The prevalence of childhood asthma

Correspondence to: Dr Xin Sun, Department of Pediatrics, Xijing Hospital, The Fourth Military Medical University, 17 Changle West Road, Xi'an, Shaanxi 710032, P.R. China

E-mail:ped_sunxin@sina.com

Key words: follistatin-like protein 1, airway smooth muscle cells, proliferation, migration is increasing worldwide (2,3). Airway smooth muscle (ASM) serves an important role in the various biological processes that are essential for the development of childhood asthma. Increased ASM mass is associated with increased asthma severity (4,5). Additionally, studies have indicated that ASM cell migration towards the airway epithelium, in response to inflammatory mediators including platelet-derived growth factor (PDGF), contributes to airway remodeling (6-8). Therefore, targeting ASM cells may be useful in treating childhood asthma.

Follistatin-like protein 1 (FSTL1), additionally referred to as TSC36, is a secreted glycoprotein that belongs to the follistatin family of proteins. It has been demonstrated to serve important roles in immunomodulation (9), embryonic development (10) and vascularization (11). In addition, FSTL1 maintains the proliferation and survival of tumor cells, and overexpression of FSTL1 significantly suppresses cell proliferation and invasion in ovarian and endometrial cancers (12). Recently, one study revealed that FSTL1 is highly expressed by macrophages in the lungs of patients with severe asthma (13). However, the role of FSTL1 in ASM cell proliferation and migration remains unknown. The present study aimed to investigate the role of FSTL1 in cell proliferation and migration mediated by PDGF subunit B (PDGF-BB) (6), a strong chemoattractant, in human ASM cells. It was demonstrated that knockdown of FSTL1 inhibited PDGF-BB-induced ASM cell proliferation and migration.

\section{Materials and methods}

Cell culture. The bronchial-tracheal-derived human ASMC cell line was purchased from the American Type Culture Collection (Manassas, VA, USA) and incubated in Dulbecco's Modified Eagle's medium (DMEM; Gibco; Thermo Fisher Scientific, Inc.) in a humidified atmosphere containing $5 \% \mathrm{CO}_{2}$ at $37^{\circ} \mathrm{C}$. ASM cells at passage 9 to 20 were used.

FSTL1 suppression by small interfering RNA (siRNA). For siRNA transfection, $1 \times 10^{5}$ cells were seeded in 6-cm dishes for $24 \mathrm{~h}$ in DMEM medium (Gibco; Thermo Fisher Scientific, Inc.). The cells $\left(1 \times 10^{5}\right.$ cells/well $)$ were subsequently transfected with $1 \mu \mathrm{l}(10 \mathrm{nM})$ FSTL1 siRNA (5'-UGCAAAUACUUACGG ACUUUU-3') or non-targeting siRNA (5'-UCUCCGAAC GUGUCACGUTT-3') (Shanghai Sangong Pharmaceutical Co., Ltd., Shanghai, China) for 18 h using Lipofectamine ${ }^{\circledR} 2000$ 
reagent (Invitrogen; Thermo Fisher Scientific, Inc., Waltham, MA, USA). Protein silencing was confirmed by western blot analysis. ASM cells were subsequently stimulated with 10 ng/ml PDGF-BB (Sigma-Aldrich; Merck KGaA, Darmstadt, Germany) for $24 \mathrm{~h}$.

Cell proliferation assay. Cell proliferation was evaluated using an MTT assay. Cells were suspended at $1 \times 10^{4}$ cells/well and $200 \mu 1$ of this suspension was plated into each well of a 96-well plate. The ASMC cells were cultured with DMEM and cells were growth-arrested prior to every experiment. They were pre-treated with FSTL1 siRNA for $24 \mathrm{~h}$, followed by PDGF-BB stimulation. Following this, the medium was removed, and $20 \mu \mathrm{l} 5 \mathrm{mg} / \mathrm{ml}$ MTT in DMEMwas added. The cells were further incubated in $5 \% \mathrm{CO}_{2}$ at $37^{\circ} \mathrm{C}$ for $4 \mathrm{~h}$. Formazan was solubilized with $100 \mu \mathrm{l}$ dimethyl sulfoxide for $10 \mathrm{~min}$. The absorbance of the solution was measured at a wavelength of $570 \mathrm{~nm}$ using a microplate reader (Spectra Max 190; Molecular Devices, LLC, Sunnyvale, CA, USA).

Cell cycle assay. The growth-arrested cells were pre-treated with FSTL1 siRNA for $24 \mathrm{~h}$, followed by PDGF-BB stimulation. The cells were harvested and fixed with ice-cold $70 \%$ $(\mathrm{v} / \mathrm{v})$ ethanol for $24 \mathrm{~h}$. Following centrifugation at 2,000 $\mathrm{x} g$ for $10 \mathrm{~min}$ at $37^{\circ} \mathrm{C}$, the cell pellet was washed with PBS and resuspended in PBS containing $50 \mu \mathrm{g} / \mathrm{ml}$ propidium iodide, $0.1 \%$ (v/v) Triton X-100 and $1 \mu \mathrm{g} / \mathrm{ml}$ DNase-free RNase. The cells were subsequently incubated for $1 \mathrm{~h}$ in the dark at room temperature. A flow cytometer (FC 500; Beckman Coulter, Inc., Brea, CA, USA) was used to elucidate cell cycle progression, and this was analyzed using Modfit software (version 3.2; Verity Software House, Topsham, ME, USA).

Cell migration assay. ASM cell migration was measured using a Transwell migration assay. ASM cells at a concentration of $5 \times 10^{4}$ cells/well, transfected with FSTL1 siRNA, were resuspended gently in DMEM/F-12 medium containing 2\% fetal bovine serum (FBS; Invitrogen; Thermo Fisher Scientific, Inc.) and added to into the upper chamber. Following this, $600 \mu \mathrm{l}$ DMEM/F-12 medium containing 10\% FBS with or without PDGF-BB was added into the lower chamber. Following incubation at $37^{\circ} \mathrm{C}$ for $24 \mathrm{~h}$, the cells on the upper membrane surface were removed by washing with PBS, and those that had migrated to the bottom side of the filter were fixed in methanol and stained with Harris hematoxylin solution for $5 \mathrm{~min}$. The mean number of migrated cells from five randomly selected optical fields under a light microscope (magnification, x100; Olympus Corporation, Tokyo, Japan) was determined.

Reverse transcription-quantitative polymerase chain reaction $(R T-q P C R)$. Total RNA was extracted from ASM cells using TRIzol ${ }^{\circledR}$ reagent (Invitrogen; Thermo Fisher Scientific, Inc.) according to the manufacturer's protocol. For mRNA detection, cDNA was generated using Moloney Murine Leukemia Virus Reverse Transcriptase (Clontech Laboratories, Inc., Mountainview, CA, USA). The expression levels of gene mRNA transcripts were analyzed using specific primers, SYBR ${ }^{\circledR}$-Green I reagent (Invitrogen; Thermo Fisher Scientific, Inc.) and the Bio-Rad iQ5 qPCR system (Takara Biotechnology Co., Ltd., Dalian, China), according to the manufacturer's protocol. The specific primers for FSTL1 were as follows: Sense, 5'-CGAGGTGGAGTTGACGAGAAAC-3' and antisense, 5'-AGGACTGGATCATCATGACGTTCT-3'. GAPDH were 5'-GGCAAATTCAACGGCACAGTC-3' (sense), 5'-GCTGACAATCTTGAGTGAGTT-3' (antisense). The PCR procedure was as follows: An initial denaturation step at $94^{\circ} \mathrm{C}$ for $4 \mathrm{~min}$, followed by 40 cycles of denaturation at $94^{\circ} \mathrm{C}$ for $20 \mathrm{sec}$, annealing at $55^{\circ} \mathrm{C}$ for $30 \mathrm{sec}$ and extension at $72^{\circ} \mathrm{C}$ for $20 \mathrm{sec}$, and a melting curve from 65 to $95^{\circ} \mathrm{C}$. GAPDH served as a control for normalizing the gene expression levels and the results were analyzed using the $2^{-\Delta \Delta C q}$ method (14). The sequences for GAPDH are as follows: 5'-GGCAAATTCAAC GGCACAGTC-3' (sense) and 5'-GCTGACAATCTTGAG TGAGTT-3' (antisense).

Western blot analysis. Cells were lysed using RIPA Cell lysis buffer (Takara Biotechnology, Co., Ltd., Dalian, China) and protein concentrations were determined using the Bicinchoninic Acid assay kit (Pierce; Thermo Fisher Scientific, Inc.). Equal amounts of protein $(30 \mu \mathrm{g})$ were separated by $10 \%$ SDS-PAGE and transferred onto polyvinylidene difluoride membranes (Whatman; GE Healthcare Life Sciences, Chalfont, UK). The membranes were blocked in 5\% nonfat milk in TBS with Tween-20 (TBST; $5 \mathrm{mM}$ Tris- $\mathrm{HCl}$ at $\mathrm{pH}$ 7.4, $136 \mathrm{mM} \mathrm{NaCl}, 0.1 \%$ Tween-20) for $1 \mathrm{~h}$ at room temperature prior to hybridization with the following primary antibodies overnight at $4^{\circ} \mathrm{C}$. Detection of rabbit anti-FSTL1 (dilution, 1:1,500; Abcam, Cambridge, UK; cat. no. 111969), mouse anti-phospho-extracellular signal-regulated kinase (ERK; dilution, 1:2,000; Santa Cruz Biotechnology, Inc., Dallas, TX, USA; cat. no. sc-81492), rabbit anti-ERK (dilution, 1:2,000; Santa Cruz Biotechnology, Inc.; cat. no. sc-292838), mouse anti-AKT (dilution, 1:2,000; Santa Cruz Biotechnology, Inc.; sc-5298), rabbit anti-phospho-AKT (dilution, 1:2,000; Santa Cruz Biotechnology, Inc.; cat. no. sc-135650) was performed. The membranes were subsequently washed three times for 5 min with TBST and incubated with bovine anti-rabbit horseradish peroxidase-conjugated secondary antibodies (dilution, 1:3,000; cat. no. sc-2385) for $1 \mathrm{~h}$ at room temperature. The resulting protein bands were visualized using an Enhanced Chemiluminescence reagent according to the manufacturer's protocol. The relative expression levels of each protein compared with GAPDH were analyzed. BandScan software (version 5.0; Glyko, Novato, CA, USA) was used for the quantification of all proteins following western blot analysis.

Statistical analysis. All experiments were performed in at least triplicate and results are expressed as the mean \pm standard deviation. Statistical comparisons were performed using one-way analysis of variance followed by the Student's t-test. $\mathrm{P}<0.05$ was considered to indicate a statistically significant difference.

\section{Results}

FSTL1 is upregulated in PDGF-BB-treated ASM cells. The present study initially measured the expression levels of FSTL1 in PDGF-BB-treated ASM cells. As presented in Fig. 1A, after $6 \mathrm{~h}$ PDGF-BB markedly increased the mRNA expression levels of FSTL1, reaching a peak at $24 \mathrm{~h}$. Additionally, 
A

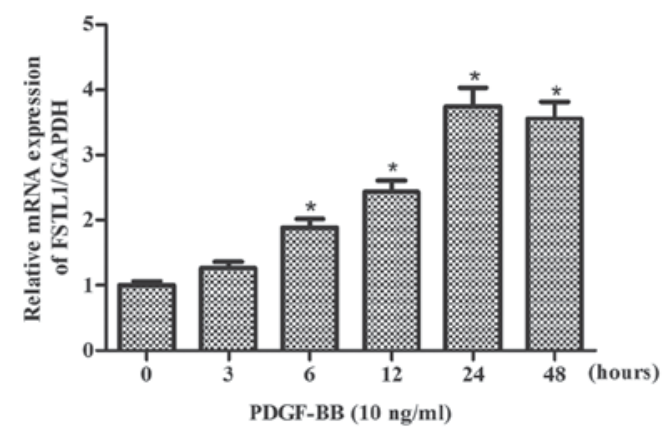

B

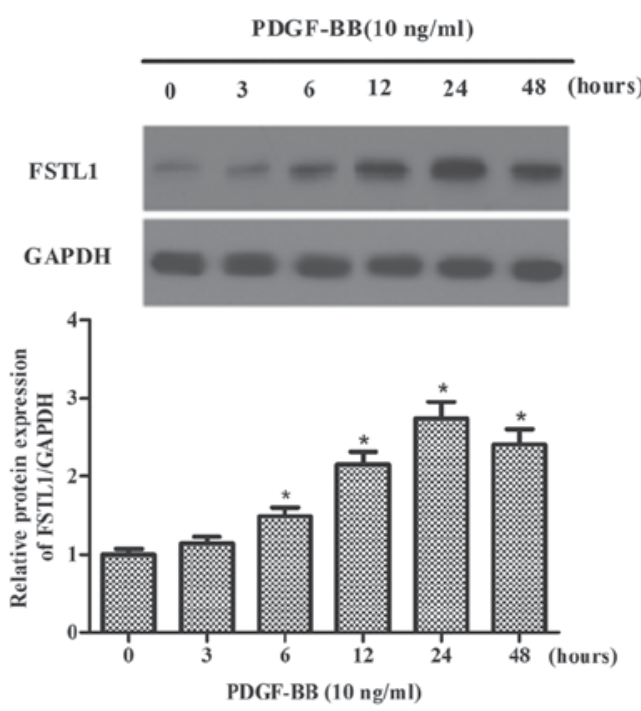

Figure 1. Expression levels of FSTL1 in ASM cells. Serum-deprived ASM cells were treated with $10 \mathrm{ng} / \mathrm{ml}$ PDGF-BB for the indicated times. (A) mRNA and (B) protein expression levels of FSTL1 increased in a time-dependent manner in PDGF-BB-stimulated ASM cells. Data are presented as the mean \pm standard deviation $(n=3)$. ${ }^{*} \mathrm{P}<0.05$ vs. $0 \mathrm{~h}$ group. FSTL1, follistatin-like protein 1; ASM, airway smooth muscle; PGDF-BB, platelet-derived growth factor subunit B.

the expression levels of the FSTL1 protein were increased by PDGF-BB (Fig. 1B) in a time-dependent manner.

Knockdown of FSTL1 expression levels in ASM cells. Following this, ASM cells were transfected with FSTL1 siRNA, and the efficiency of transfection was evaluated by western blot and RT-qPCR analysis. Western blot data revealed that transfection of FSTL1 siRNA markedly decreased the expression levels of FSTL1 protein $(\mathrm{P}=0.016$; Fig. 2A). Consistent with the results of western blot, western blot analysis demonstrated that FSTL1 siRNA inhibited the mRNA expression levels of FSTL1 (P=0.029; Fig. 2B).

Knockdown of FSTL1 inhibits PDGF-BB-induced ASM cell proliferation. The role of FSTL1 in PDGF-BB-stimulated proliferation of ASM cells was subsequently investigated. As presented in Fig. 3A, compared with the control group, PDGF-BB treatment markedly increased cell proliferation
A
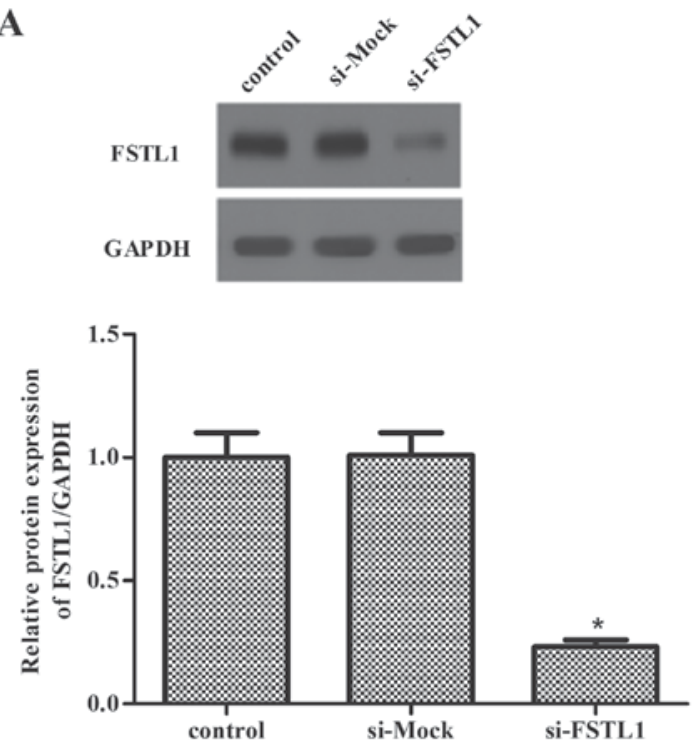

B

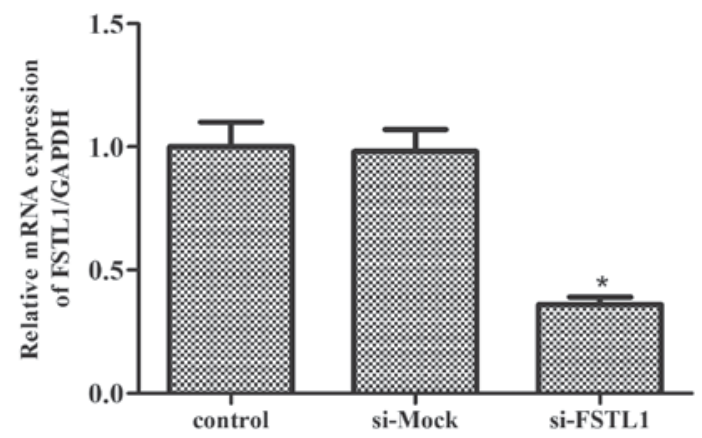

Figure 2. Knockdown of FSTL1 expression levels in airway smooth muscle cells. Cells were transfected with 10 nM FSTL1 siRNA. A total of $24 \mathrm{~h}$ following transfection, cells were lysed for (A) western blot analysis or (B) RNA isolation and reverse transcription-quantitative polymerase chain reaction analysis. Data are presented as the mean \pm standard deviation $(n=3)$. ${ }^{*} \mathrm{P}<0.05$. FSTL1, follistatin-like protein 1 ; si, small interfering.

$(\mathrm{P}=0.034 ; \mathrm{P}=0.026)$. However, knockdown of FSTL1 significantly inhibited PDGF-BB-induced ASM cell proliferation $(\mathrm{P}=0.043 ; \mathrm{P}=0.036)$.

To further examine the effect of FSTL1 on PDGF-BB-induced ASM cell proliferation, cell cycle progression was evaluated by flow cytometry. As presented in Fig. 3B, PDGF-BB induced the entry of ASM cells to the synthesis phase (S-phase) to undergo proliferation, with $62.5 \pm 1.6 \%$ cells in $\mathrm{G} 0 / \mathrm{G} 1$ phase (compared with $73.1 \pm 2.5 \%$ in the control; $\mathrm{P}=0.041$ ) and $31.2 \pm 1.9 \%$ in S-phase (compared with $19.4 \pm 1.3 \%$ in the control; $\mathrm{P}=0.031)$, whereas the knockdown of FSTL1 significantly arrested the cell cycle at the $\mathrm{G} 2 / \mathrm{M}$ phase $(18.6 \pm 1.7$ vs. $5.8 \pm 1.1 \%$ in the PDGF-BB group; $\mathrm{P}=0.028$ ).

Knockdown of FSTL1 inhibits PDGF-BB-induced ASM cell migration. Following this, the effect of FSTL1 on ASM cell migration induced by PDGF-BB was examined using a Transwell migration assay. As presented in Fig. 4, PDGF-BB 
A

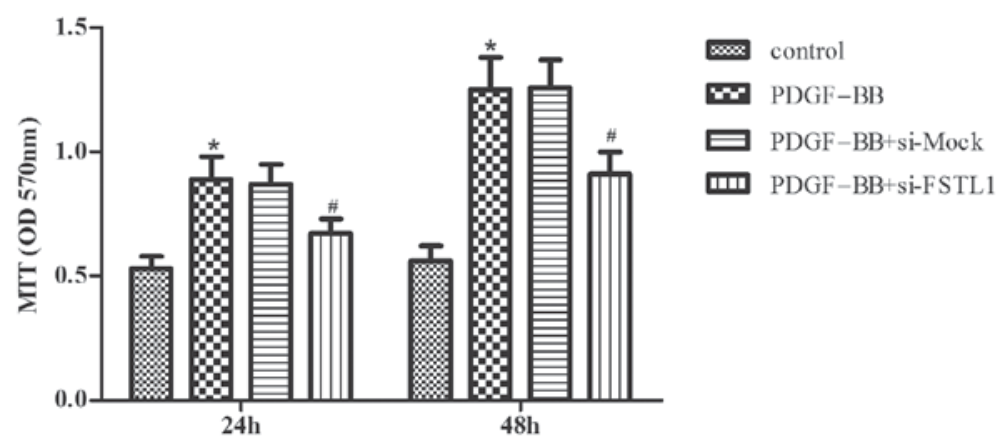

B

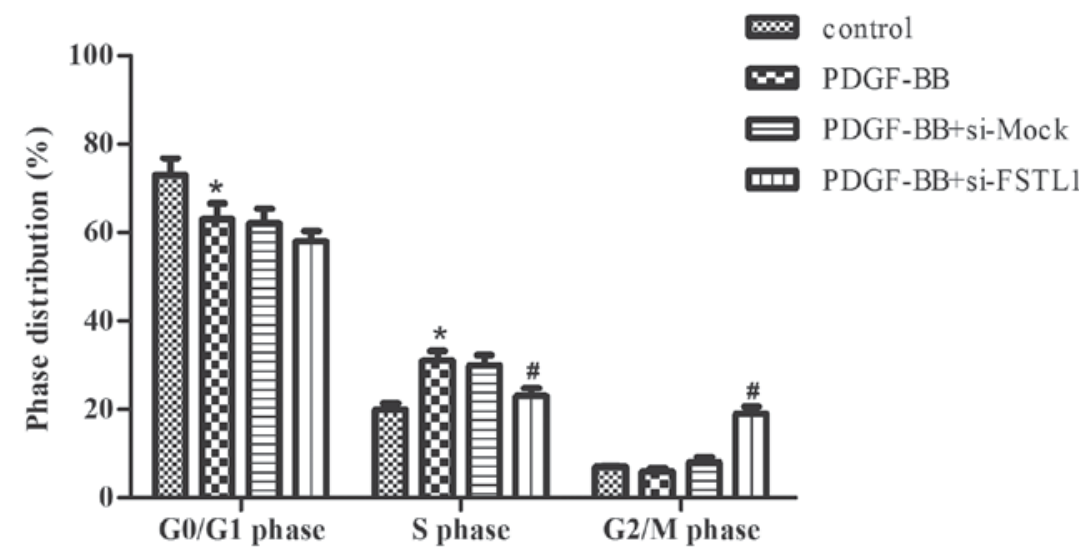

Figure 3. Knockdown of FSTL1 inhibits PDGF-BB-induced airway smooth muscle cell proliferation. Growth-arrested cells were treated with or without PDGF-BB in the presence or absence of FSTL1 siRNA for $24 \mathrm{~h}$. (A) Cell proliferation was evaluated using an MTT assay. (B) Cell cycle progression was determined using flow cytometry. Data are presented as the mean \pm standard deviation $(\mathrm{n}=3)$. ${ }^{*} \mathrm{P}<0.05$ vs. control group; ${ }^{*} \mathrm{P}<0.05$ vs. PDGF-BB group. FSTL1, follistatin-like protein 1; PGDF-BB, platelet-derived growth factor subunit B; si, small interfering.

resulted in a 2.59-fold increase in the number of cells that migrated through the membrane compared with the untreated control $(\mathrm{P}=0.023)$, whereas knockdown of FSTL1 markedly inhibited PDGF-BB-induced ASM cell migration $(\mathrm{P}=0.036)$.

Knockdown of FSTL1 inhibits PDGF-BB-induced activation of ERK and AKT in ASM cells. To investigate the underlying mechanisms by which FSTL1 affected PDGF-BB-induced ASM cell proliferation and migration, the effect of FSTL1 on the activation of ERK and AKT in PDGF-BB-stimulated ASM cells was examined. As presented in Fig. 5, the protein expressions levels of p-ERK1/2 and p-AKT increased following PDGF-BB stimulation, whereas the knockdown of FSTL1 markedly inhibited PDGF-induced expression levels of $\mathrm{p}$-ERK1/2 and $\mathrm{p}-\mathrm{AKT}$.

\section{Discussion}

Abnormal proliferation and migration of ASM cells serve roles in airway remodeling and contribute to airway hyper-responsiveness. The present study demonstrated that
PDGF-BB stimulation upregulated FSTL1 expression levels in ASM cells in vitro. Knockdown of FSTL1 inhibited cell proliferation and arrested the cell cycle in the $\mathrm{G} 2 / \mathrm{M}$ phase in PDGF-BB-stimulated ASM cells. Additionally, FSTL1 knockdown inhibited PDGF-BB-induced ASM cell migration. Furthermore, knockdown of FSTL1 caused downregulation of p-ERK and p-AKT protein expression levels induced by PDGF-BB in ASM cells.

A previous study reported that FSTL1 acted as a bone morphogenetic protein 4 antagonist during lung development (15). FSTL1 expression is induced in response to lung injury and mediates the accumulation of myofibroblasts and subsequent fibrosis; inhibition of FSTL1 with a neutralizing antibody in mice reduced bleomycin-induced fibrosis in vivo (16). The present study demonstrated that PDGF-BB stimulation upregulated FSTL1 expression levels in ASM cells in vitro. These data suggested that FSTL1 may serve a critical role in in asthmatic ASM remodeling.

FSTL1 has been reported to inhibit proliferation and invasion, and to induce apoptosis of cancer cells in vitro $(17,18)$. In 


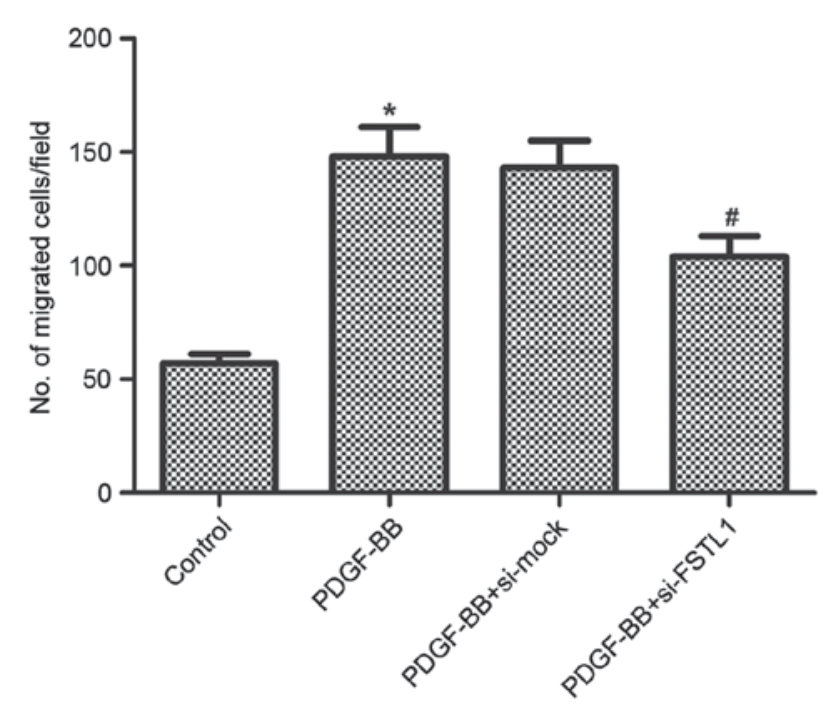

Figure 4. Knockdown of FSTL1 inhibits PDGF-BB-induced airway smooth muscle cell migration. The growth-arrested cells were treated with or without PDGF-BB in the presence or absence of FSTL1 siRNA. After $24 \mathrm{~h}$, cell migration was evaluated using a Transwell assay. Data are presented as the mean \pm standard deviation $(n=3)$. ${ }^{*} \mathrm{P}<0.05$ vs. control group; ${ }^{\#} \mathrm{P}<0.05$ vs. PDGF-BB group. FSTL1, follistatin-like protein 1; PGDF-BB, platelet-derived growth factor subunit B; si, small interfering.

addition, increasing evidence indicates that PDGF is involved in the pathophysiology of asthma, and that PDGF is a potent mitogen that may mediate ASM cell proliferation and migration (19-21). The present study revealed that knockdown of FSTL1 inhibited cell proliferation and arrested the cell cycle in the G2/M phase in PDGF-BB-stimulated ASM cells. In addition, it was observed that the knockdown of FSTL1 inhibited PDGF-BB-induced ASM cell migration.

It has been reported that the dual phosphoinositide 3-kinase (PI3K)/AKT and ERK pathways may regulate ASM cell proliferation and migration (22-24). AKT is a primary downstream target of PI3K, activated in response to various stimuli, growth factors and hormones. ERK1/2 belongs to the mitogen-activated protein kinase family and is located downstream of the Raf/Ras/mitogen-activated protein kinase kinase cascade. A previous study demonstrated that ERK and AKT activation was significantly greater in ASM cells from asthmatic, compared with non-asthmatic, subjects (25), and that the inhibition of the ERK1/2 or PI3K/AKT signaling pathway significantly inhibited ASM proliferation (26). Additionally, one study reported that the overexpression of FSTL1 protected cultured neonatal rat ventricular myocytes from hypoxia/reoxygenation-induced apoptosis, and that this protective effect was dependent on the upregulation of AKT and ERK activities. The knockdown of FSTL1 in cardiac myocytes decreased basal AKT signaling and increased cell apoptosis (27). The present study revealed that PDGF-BB-induced ASM cell migration was partially mediated by inhibition of the activation of ERK and AKT. These data are consistent with those of previous studies in which the activation of ERK and AKT were demonstrated to mediate ASM proliferation and migration induced by various growth factors, including PDGF-BB $(20,28,29)$. Furthermore, the present study revealed that the knockdown of FSTL1 markedly inhibited PDGF-BB-induced protein expression levels of p-ERK and p-AKT.
A
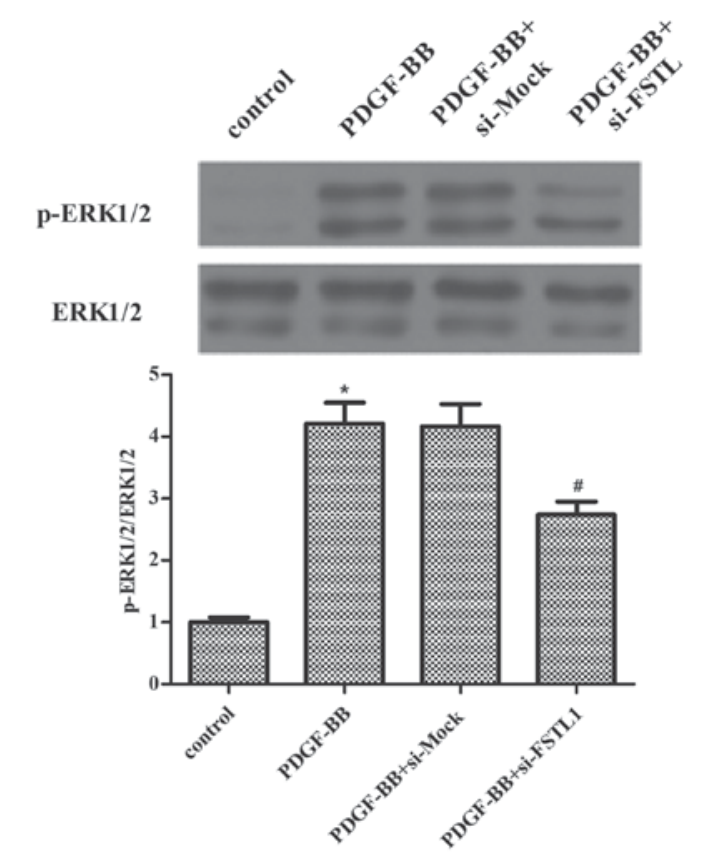

B
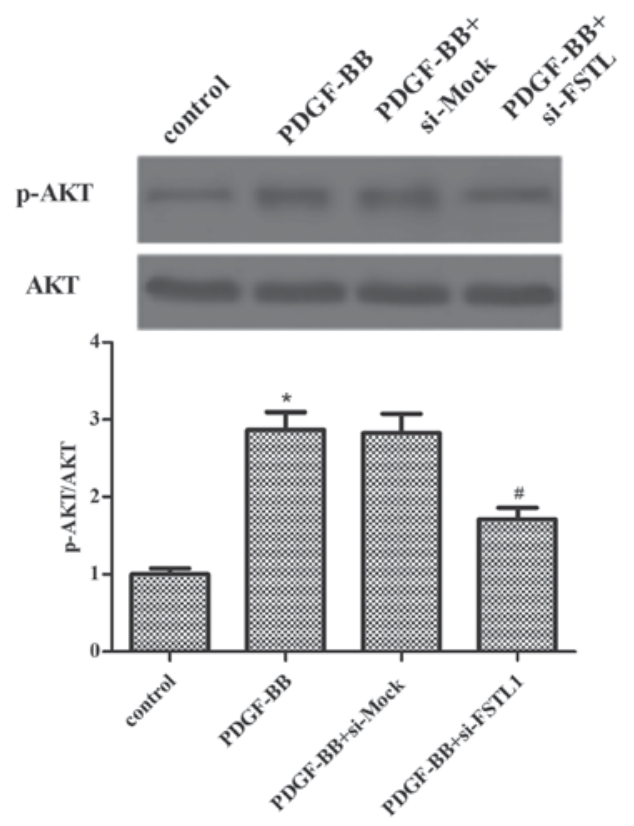

Figure 5. Knockdown of FSTL1 inhibits PDGF-BB-induced activation of ERK and AKT in airway smooth muscle cells. Growth-arrested cells were treated with or without PDGF-BB in the presence or absence of FSTL1 siRNA for $30 \mathrm{~min}$. The protein expression levels of (A) p-ERK1/2 compared with ERK1/2, and (B) p-AKT compared with AKT, were assessed by western blotting and analyzed by densitometry. Data are presented as the mean \pm standard deviation $(n=3)$. ${ }^{*} \mathrm{P}<0.05$ vs. control group; ${ }^{\#} \mathrm{P}<0.05$ vs. $\mathrm{PDGF}-\mathrm{BB}$ group. FSTL1, follistatin-like protein 1; PGDF-BB, platelet-derived growth factor subunit B; ERK, extracellular signal-regulated kinase; AKT, protein kinase $\mathrm{B}$; $\mathrm{p}$, phosphorylated; si, small interfering.

In conclusion, the results of the present study demonstrated that knockdown of FSTL1 inhibited ASM cell proliferation and migration induced by PDGF-BB at least partially via inhibiting the activation of ERK and AKT. These results provide novel insight into the pathogenesis of airway remodeling in childhood asthma and FSTL1 may be a possible therapeutic strategy for the treatment of asthma. 


\section{References}

1. Noutsios GT and Floros J: Childhood asthma: Causes, risks, and protective factors; a role of innate immunity. Swiss Med Wkly 144: w14036, 2014.

2. Asher MI, Montefort S, Björkstén B, Lai CK, Strachan DP, Weiland SK and Williams H; ISAAC Phase Three Study Group: Worldwide time trends in the prevalence of symptoms of asthma allergic rhinoconjunctivitis, and eczema in childhood: ISAAC Phases One and Three repeat multicountry cross-sectional surveys. Lancet 368: 733-743, 2006.

3. De Marco R, Cappa V, Accordini S, Rava M, Antonicelli L, Bortolami O,Braggion M, Bugiani M, Casali L, Cazzoletti L, et al: Trends in the prevalence of asthma and allergic rhinitis in Italy between 1991 and 2010. Eur Respir J 39: 883-892, 2012.

4. Zuyderduyn S, Sukkar M, Fust A, Dhaliwal S and Burgess JK: Treating asthma means treating airway smooth muscle cells. Eur Respir J 32: 265-274, 2008.

5. Hirst SJ, Martin JG, Bonacci JV, Chan V, Fixman ED, Hamid QA, Herszberg B, Lavoie JP, McVicker CG, Moir LM, et al: Proliferative aspects of airway smooth muscle. J Allergy Clin Immunol 114 (2 Suppl): S2-S17, 2004.

6. Carlin SM, Roth M and Black JL: Urokinase potentiates PDGF-induced chemotaxis of human airway smooth muscle cells. Am J Physiol Lung Cell Mol Physiol 284: L1020-L1026, 2003.

7. Madison JM: Migration of airway smooth muscle cells. Am J Respir Cell Mol Biol 29: 8-11, 2003

8. Parameswaran K, Radford K, Zuo J, Janssen L, O'byrne P and Cox P: Extracellular matrix regulates human airway smooth muscle cell migration. Eur Respir J 24: 545-551, 2004.

9. Le Luduec JB, Condamine T, Louvet C, Thebault P, Heslan JM, Heslan M, Chiffoleau E and Cuturi MC: An immunomodulatory role for follistatin-like 1 in heart allograft transplantation. Am J Transplant 8: 2297-2306, 2008

10. Esterberg R, Delalande JM and Fritz A: Tailbud-derived Bmp4 drives proliferation and inhibits maturation of zebrafish chordamesoderm. Development 135: 3891-3901, 2008.

11. Ouchi N, Oshima Y, Ohashi K, Higuchi A, Ikegami C, Izumiya $\mathrm{Y}$ and Walsh K: Follistatin-like 1, a secreted muscle protein, promotes endothelial cell function and revascularization in ischemic tissue through a nitric-oxide synthase-dependent mechanism. J Biol Chem 283: 32802-32811, 2008.

12. Chan QK, Ngan HY, Ip PP, Liu VW, Xue WC and Cheung AN: Tumor suppressor effect of follistatin-like 1 in ovarian and endometrial carcinogenesis: A differential expression and functional analysis. Carcinogenesis 30: 114-121, 2009.

13. Miller M, Beppu A, Rosenthal P, Pham A, Das S, Karta M, Song DJ, Vuong C, Doherty T, Croft M, et al: Fstl1 promotes asthmatic airway remodeling by inducing oncostatin $\mathrm{M}$. J Immunol 195: 3546-3556, 2015.

14. Livak KJ and Schmittgen TD: Analysis of relative gene expression data using real-time quantitative PCR and the 2(-Delta Delta C(T)) method. Methods 25: 402-408, 2001.

15. Geng Y, Dong Y, Yu M, Zhang L, Yan X, Sun J, Qiao L, Geng H, Nakajima M, Furuichi T, et al: Follistatin-like 1 (Fstl1) is a bone morphogenetic protein (BMP) 4 signaling antagonist in controlling mouse lung development. Proc Natl Acad Sci USA 108 7058-7063, 2011
16. Dong Y, Geng Y, Li L, Li X, Yan X, Fang Y, Li X, Dong S, Liu X, Li X, et al: Blocking follistatin-like 1 attenuates bleomycin-induced pulmonary fibrosis in mice. J Exp Med 212: 235-252, 2015.

17. Johnston I, Spence HJ, Winnie JN, McGarry L, Vass JK, Meagher L, Stapleton G and Ozanne BW: Regulation of a multigenic invasion programme by the transcription factor, AP-1: Re-expression of a down-regulated gene, TSC-36, inhibits invasion. Oncogene 19: 5348-5358, 2000.

18. Sumitomo K, Kurisaki A, Yamakawa N, Tsuchida K, Shimizu E, Sone $\mathrm{S}$ and Sugino H: Expression of a TGF-betal inducible gene, TSC-36, causes growth inhibition in human lung cancer cell lines. Cancer Lett 155: 37-46, 2000.

19. Wei Y, Xu YD, Yin LM, Wang Y, Ran J, Liu Q, Ma ZF, Liu YY and Yang YQ: Recombinant rat CC10 protein inhibits PDGF-induced airway smooth muscle cells proliferation and migration. Biomed Res Int 2013: 690937, 2013.

20. Liu W, Kong H, Zeng X, Wang J, Wang Z, Yan X, Wang Y, Xie $\mathrm{W}$ and Wang H: Iptakalim inhibits PDGF-BB-induced human airway smooth muscle cells proliferation and migration. Exp Cell Res 336: 204-210, 2015.

21. Ning Y, Huang H, Dong Y, Sun Q, Zhang W, Xu W and Li Q: 5-Aza-2'-deoxycytidine inhibited PDGF-induced rat airway smooth muscle cell phenotypic switching. Arch Toxicol 87: 871-881, 2013.

22. Day RM, Lee YH, Park AM and Suzuki YJ: Retinoic acid inhibits airway smooth muscle cell migration. Am J Respir Cell Mol Biol 34: 695-703, 2006.

23. Lee JH, Johnson PR, Roth M, Hunt NH and Black JL: ERK activation and mitogenesis in human airway smooth muscle cells. Am J Physiol Lung Cell Mol Physiol 280: L1019-L1029, 2001.

24. Xie S, Sukkar MB, Issa R, Oltmanns U, Nicholson AG and Chung KF: Regulation of TGF-beta 1-induced connective tissue growth factor expression in airway smooth muscle cells. Am J Physiol Lung Cell Mol Physiol 288: L68-L76, 2005.

25. Burgess JK, Lee JH, Ge Q, Ramsay EE, Poniris MH, Parmentier J, Roth M, Johnson PR, Hunt NH, Black JL and Ammit AJ: Dual ERK and phosphatidylinositol 3-kinase pathways control airway smooth muscle proliferation: Differences in asthma. J Cell Physiol 216: 673-679, 2008.

26. Stewart AG, Xia YC, Harris T, Royce S, Hamilton JA and Schuliga M: Plasminogen-stimulated airway smooth muscle cell proliferation is mediated by urokinase and annexin A2, involving plasmin-activated cell signalling. Br J Pharmacol 170: 1421-1435, 2013.

27. Oshima Y, Ouchi N, Sato K, Izumiya Y, Pimentel DR and Walsh K: Follistatin-like 1 is an Akt-regulated cardioprotective factor that is secreted by the heart. Circulation 117: 3099-3108, 2008.

28. Movassagh H, Shan L, Halayko AJ, Roth M, Tamm M, Chakir J and Gounni AS: Neuronal chemorepellent Semaphorin 3E inhibits human airway smooth muscle cell proliferation and migration. J Allergy Clin Immunol 133: 560-567, 2014.

29. Walker TR, Moore SM, Lawson MF, Panettieri RA Jr and Chilvers ER: Platelet-derived growth factor-BB and thrombin activate phosphoinositide 3-kinase and protein kinase B: Role in mediating airway smooth muscle proliferation. Mol Pharmacol 54: 1007-1015, 1998. 